\title{
Can statelessness be legally productive? The struggle for the rights of noncitizens in Russia.
}

Abstract. Nearly 30 years since the collapse of the Soviet bloc, there are still people who have never in their lives held any passport other than that of the Soviet Union. They are de jure stateless. However, their statelessness can also be legally productive if strategically challenged. This legal productivity arises from the mobilization of human rights protections embedded in de jure statelessness by local legal actors in a given, national immigration context, and extending them to secure the rights of de facto stateless: undocumented migrants and asylum seekers. I illustrate this using a case study of the recent litigation for the rights of Mr Mskhiladze - a stateless person born in the Georgian USSR - before the Russian Constitutional Court (2017) and the European Court of Human Rights (2018). Conceptually, my paper testifies to a productive relationship between a de jure and de facto statelessness in the post-Soviet context.

Keywords: de jure statelessness, de facto statelessness, detention, post-Soviet Russia, Mskhiladze, 


\section{Introduction}

Mr Noe Georgiyevich Mskhiladze was born in the Georgian Republic of the USSR in 1972. In 1988, he came to St Petersburg (then Leningrad) to study at a professional technical high school. Upon the completion of his studies he left for Georgia, however the following year he returned to Russia, married a Russian citizen, and has not left St Petersburg ever since. Mr Mskhiladze was not necessarily a law-abiding citizen. Because of his several criminal offences, he could not obtain Russian citizenship upon the dissolution of the Soviet Union in 1991. ${ }^{1}$ His USSR passport expired while he was in custody, and Mr Mskhiladze found himself in the position of a stateless person. He led a relatively uneventful life in $\mathrm{St}$ Petersburg: he worked in the shadow economy, accessed healthcare privately and was trying to make ends meet like the vast majority of post-Soviet citizens. The difference was that $\mathrm{Mr}$ Mskhiladze's official identity documents placed him in a world that no longer existed.

Towards the end of 2015, the Federal Migration Service (FMS) ${ }^{2}$ stopped $\mathrm{Mr}$ Mskhiladze during a routine documents check. Mr Mskhiladze could only show to the authorities his expired Soviet passport. The FMS insisted on treating Mr Mskhiladze as an 'ordinary immigration law offender' (Kubal, 2016). While the court noted Mr Mskhiladze was a former USSR national, it sentenced him to expulsion and placed him in a detention centre for foreigners. Mr Mskhiladze was ready to leave for Georgia, but could not do it,

\footnotetext{
${ }^{1}$ In 1991, it was relatively easy to become a Russian citizen. No residency requirements, knowledge of Russian language or culture, income level or renunciation of previous citizenship - which, since 2002, became the conditions for citizenship - were required. The only condition was a clear criminal record (Shevel 2012: 132).

${ }^{2}$ Federal Migration Service (FMS) was a Russian immigration enforcement agency. It was disbanded as an independent organization by Presidential Decree No. 156 as of 5 April 2016. Its functions were transferred to the newly established Main Directorate for Migration of the Ministry of Interior (GUVM MVD). .
} 
since Georgia did not recognize him as its citizen. His future amounted to a bleak prospect of potentially indefinite administrative detention without even a slim chance of actual removal, as Georgian USSR has ceased to exist long ago.

Indeed, nearly thirty years since the collapse of the Soviet bloc there are still people who, never in their lives, have held any passport other than that of the Soviet Union. They are stateless in every meaning of this term - both de jure and de facto (Vlieks, 2017) ${ }^{3}$. Their statelessness is a residue (Cole, 2017) of the post-imperial identity politics (Shevel, 2009). Some were intentionally made stateless by the new exclusionary citizenship regimes of Latvia and Estonia (Brubaker, 1992), others fell through the cracks of the ever changing citizenship laws, never quite fitting the evolving definition of a citizen, neither in Russia nor in the post-Soviet republics (Levin, 2018; Shevel, 2012).

The relationship between de jure and de facto statelessness in Russia is a complex one, however, as I argue in this paper, it can also be legally productive if strategically challenged. The legal productivity arises from the mobilization of the international human rights protections embedded in de jure statelessness by local legal actors in a given, national immigration context to secure the rights of other undocumented migrants and asylum seekers, who are de facto stateless. The case of Mr Mskhiladze before the Russian Constitutional Court (RCC, 2017) and the European Court of Human Rights (ECtHR, 2018) illustrates this. The legal battle to free Mr Mskhiladze from prolonged detention led to elements of the Code of Administrative Offences (CAO) declared unconstitutional by the Russian Constitutional Court (RCC). This helped secure the enforceable (human) right to liberty (Art 5 ECHR) for other groups of non-deportable noncitizens in Russian detention centres. It was particularly

\footnotetext{
${ }^{3}$ I am aware that the distinction between de jure and de facto statelessness is controversial. I employ it as a heuristic and define it on pp. $9-10$ of this paper.
} 
productive to challenge the long-term detention of a new category of de facto stateless people in the post-Soviet context: Ukrainians who fled to Russia in the aftermath of the military conflict in Eastern Ukraine. ${ }^{4}$

The 'thick description' (Geertz 2008) and analysis of a specific local citizenship and immigration regime, as a form of domination and control over citizenship can shed light onto how exactly the productive nature of the relationship between de jure and de facto statelessness can be galvanised. The situation of stateless former USSR citizens in Russia translates itself much easier to the legal culture of Russian judiciary characterised by rigid formalism and conservatism (Hendley, 2017; Kubal, 2016, 2018; Kurkchiyan, 2009). It is not because Russian judges are drawn to the powerless and have special sympathy for the stateless. Rather, the formal legal clarity of the post-Soviet de jure statelessness made the case of Mr Mskhiladze relatively easy to adjudicate especially when compared with more complex cases of other - and more recent - de facto stateless. Another important factor was a strong group of pro-bono immigration cause lawyers gathered around the 'Migration and Law' network (for their detailed description and characteristic, see Kubal, 2019), who fought this case through the ranks of the Russian justice system all the way to the RCC and the ECtHR. Upon the favourable landmark decision, they stopped at nothing 'to push the authorities into compliance' (Golubok quoted in Kubal 2019), and gradually extended the

\footnotetext{
${ }^{4}$ While the changes simplifying the acquisition of Russian citizenship for Eastern Ukrainians signed by President Putin on 24 April 2019 can be seen as politically solving the question of de facto Ukrainian statelessness in Russia, this does not affect the conclusions contained in this paper. My analysis focuses on the legally productive relationship between de jure and de facto statelessness in the area of human rights and my conclusions hold true also for the Kyrgyz and Uzbek migrants without effective nationality in Russia. However, given the relatively high numbers of the de facto stateless Eastern Ukrainians in Russia prior to 2019, I decided to use this group as a poignant illustration of my point.
} 
interpretation of the judgment to protect migrants and asylum seekers in other precarious legal situations. These were the specific conditions, which testified to the legal productivity of statelessness and led to the diffusion of rights and protections to people without effective nationality in the post-Soviet context. ${ }^{5}$

This paper is informed by a five-month long ethnographic fieldwork in pro-bono legal aid clinics for migrants and refugees in Russia belonging to the activist 'Migration and Law' network in 2014. I conducted daily observations of the relationships between the migrant and refugee clients and their lawyers; I shadowed the lawyers in courts when they were representing their clients (overall, I conducted fifty court observations). I also accompanied the migrants to the meetings with the local FMS officers either applying for asylum or inquiring about the status of their application. Throughout my fieldwork, I did not actively seek stateless individuals, but the phenomenon of post-Soviet statelessness came to the forefront of my research whilst interrogating the various socio-legal predicaments of migrants and refugees in post-Soviet Russia. I supplemented this material with follow up interviews with two high profile immigration lawyers who represented Mr Mskhiladze before the RCC the ECtHR between 2017 and 2019.

My argument proceeds in three parts. In the first section, I present the historical context of post-Soviet statelessness and the scale of this phenomenon in contemporary Russia. I then use the case of Mr Mskhiladze to illustrate a successful legal challenge of postSoviet statelessness before the RCC and the ECtHR. The third section reveals how this landmark decision has helped secure the rights of other noncitizens in de facto stateless legal

\footnotetext{
${ }^{5}$ I limit my conclusions about the legally productive relationship between de jure and de facto statelessness to the post-Soviet context, which I studied empirically. I welcome further research to 'test' this relationship in other socio-legal and jurisdictional contexts.
} 
position in Russia. I conclude with more conceptual observations around the legally productive relationship between de jure and de facto statelessness.

\section{Statelessness in post-Soviet space}

A lot has been said about the statelessness phenomenon upon the collapse of the Soviet Union (Buckley, Blair A. Ruble, \& Hofmann, 2008; Pilkington, 1998); this statelessness is 'sticky', it is unlikely to disappear within one generation, but continues as one of the many Soviet legacies (Levin, 2018). The late 1980's with their 'extremist politics, volatile economics and bewildering legislation' (Kurkchiyan, 2003: 26) saw an increase in ethnic tensions in the different corners and contexts of the crumbling Soviet Union. The USSR was undergoing radical political transformations and its citizens responded 'with their feet' (Hirschman, 1970) - some moved for safety (Pilkington, 1998), while others moved for schooling, jobs, or marriage.

When 'the music finally stopped', and Soviet documents were being replaced by postSoviet passports (Levin, 2018: 26), two forms of citizenship policy emerged. Oxana Shevel distinguished between provisions that 'granted preferential treatment to coethnics ${ }^{6}$ (Shevel, 2009: 273) and 'zero-option' policies, where, whoever was on the territory of a newly independent post-Soviet republic, would automatically receive the new citizenship. ${ }^{7}$ The exclusionary citizenship policy based on jus sanguinis, and privileging ethnicity over longterm residence, is well documented in the literature (Brubaker, 1992; Chinn \& Truex, 1996). This policy made thousands of former Soviet residents of Russian nationality in Estonia and

\footnotetext{
${ }^{6}$ Not only in Estonia and Latvia but also Armenia, Belarus, Kazakhstan, Lithuania and Turkmenistan (Shevel 2009: 274).

${ }^{7}$ The latter citizenship policy without provisions for coethnics was in Azerbaijan, Georgia, Moldova, Russia, Tajikistan, Ukraine and Uzbekistan (Shevel 2009: 274).
} 
Latvia stateless as a matter of national identity politics and 'righting' the historical wrongs (Fein \& Straughn, 2014). In response, many former Soviet citizens actively refused to naturalise, some even say that they 'choose statelessness' (Vetik, 2011) as a 'silent protest to what they saw as an unjust act of expatriation' (Fein \& Straughn, 2014: 701). The 'zerooption' policy was based, instead, on the concept of jus soli and civic citizenship (Shevel 2009: 274). Whilst it was arguably very inclusive, Shevel attributed this inclusivity to an 'unintended side effect of contested politics of national identity' shared by many new states in the immediate aftermath of the Soviet Union collapse (Shevel 2009: 283). The civic citizenship policy largely reduced potential statelessness, but it did not eradicate it completely. The 'zero-option' policy, despite comprehensive rhetoric, actually did entail some exceptions - it proved particularly exclusionary with regard to mobile Soviet citizens (including coethnics) residing outside the territory of a state at the time of the passing of the law, or those with an outstanding criminal convictions. Additional problems stemmed from the everyday and interminable bureaucratic caveats (Levin, 2018). Unsurprisingly, many currently stateless persons at some point simply realized that 'their papers were no longer in order' (Humphrey, 2002: 26)

The United Nations High Commissioner for Refugees (UNHCR) estimates that there are around 91,000 persons under its statelessness mandate in Russia (UNHCR 2018). Like Mr Mskhiladze, a number of them are in long-term, potentially indefinite detention in Russia. The statistics of the Main Directorate for Migration of the Ministry of Interior (GUVM MVD) combined with reports by a Russia-wide network of immigration lawyers 'Migration and Law', demonstrate that in 2017 there were between 263 and 500 individuals in long-term detention in Russia, who could not be administratively removed (on file with the Author).

[Table 1 about here] 
A quick look through the statistical profile of the detained, de jure or de facto stateless persons demonstrates that the majority of them are from former USSR republics: Ukraine, Kazakhstan, Uzbekistan, Georgia (Table 1). The great majority of them (92 per cent) were born before 1991, i.e. at the time of their birth they were Soviet citizens with USSR passports. Like Mr Mskhiladze, a proportion of them were already in Russia at the time of the dissolution of the USSR, but for one reason or another, they did not manage to secure Russian citizenship.

\section{Exploring the relationship between de jure and de facto statelessness}

Conceptually, de jure statelessness refers to 'a person not considered as a national by any State under the operation of its law' (according to the 1954 UN Convention relating to the Status of Stateless Persons). De facto statelessness has not been legally defined; the closest formal definition comes from UNHCR's policy paper denoting 'persons outside the country of their nationality who are unable or, for valid reasons, are unwilling to avail themselves of the protection of that country' (Massey 2010: 61). In the literature, de facto statelessness has been used to refer to a situation where the nationality status is simply not known (White 2009), to refer to a state of ineffective nationality (Kingston 2014, Parsons \& Lawreniuk 2018), to denote the condition shared by some undocumented migrants (Blitz \& OteroIglesias, 2011), or some refugees (Gruberg 2011).

What is the relationship between de jure and de facto statelessness from a rightsbased perspective? While de jure statelessness arguably denotes the most extreme position in the constellation of the different legal statuses, rights and belongings that the literature came to recently call 'the assemblage of noncitizenship' (Landolt \& Goldring, 2015), the number of the international human rights protections afforded to de jure stateless is arguably higher than to those in de facto statelessness. It is a status well protected in international law (two 
UN conventions) and local human rights jurisprudence (e.g. the European Court of Human Rights, see Abramenko 2019, Lambert 2018). This, as Sigona argues, 'complicates Hannah Arendt's insightful characterization of stateless people as rightless' (2016: 263), but also shows an opportunity for the legally productive mobilisation of these rights by people in $d e$ facto stateless situations. While the international legal instruments encourage such interpretation (1961 Convention on the Reduction of Statelessness, especially Resolution No. I, see Massey 2010: i), the scholarship on the lived experiences of de facto statelessness reveals that this rarely occurs in practice (Blitz \& Otero-Iglesias, 2011, Redclift 2013a, 2013b, Sigona 2016). Instead, people with ineffective nationality quite often find themselves locked in a complex legal limbo.

My paper demonstrates how people in the de facto stateless situation can draw on the legal-technical nature of de jure statelessness to claim protection for their rights in a specific socio-legal context of post-Soviet Russia. A strategic use of the human rights protections embedded in de jure statelessness can be extended to people in de facto stateless situations, thereby testify to a legally productive relationship between these two forms of statelessness.

What follows from nuancing the relationship between de jure and de facto statelessness is a somewhat bolder response to a question originally posed by Katja Swider (2017) 'Why end statelessness'? When in 2014, UNHCR launched its ten-year \#IBelong Campaign to end statelessness by 2024 (UNHCR, 2014), some researchers actually questioned whether the elimination of statelessness as a policy goal should be pursued over protecting the rights (including human rights) of stateless persons (Swider, 2017: 191, also Bloom, Tonkiss, \& Cole, 2017). Confusing the protection of stateless persons with the reduction of statelessness, and treating citizenship as a gateway to human rights may result in a regime that forces stateless people to take up a specific nationality even if that comes with 
little or no protections, or actually locks people in dangerous and precarious situations. This seems particularly pertinent to the situation of many currently stateless persons in post-Soviet Russia (Swider 2017). Viewing statelessness as a problem 'to be solved' by channelling people to acquire different nationalities may actually result in creating more vulnerabilities. I concur with Swider, that at the normative level, priority should be given to the protection of rights of stateless persons over eradication of their statelessness, especially, since the human rights protection regime around de jure statelessness can actually become a legally productive platform to help secure rights for people without an effective nationality.

\section{The successful legal challenge to post-Soviet statelessness}

Let me return to Mr Mskhiladze. In the opening paragraphs of this paper, he found himself in a detention centre, with an expulsion order to a country that no longer existed.

In view of these developments, the Federal Bailiffs Service (the body responsible for the enforcement of the courts' decisions in Russia) petitioned the St Petersburg court to terminate the enforcement proceedings of the removal of Mr Mskhiladze and have him released from detention. It has to be stressed that the Federal Bailiffs Service did not file this petition out of goodwill and sympathy toward the stateless Mr Mskhiladze, but because the impossibility to enforce this judgment 'looked bad' in their performance records (see: McCarthy, 2018). The St Petersburg court however dismissed this petition and insisted that there was no statutory basis in the law for granting such application.

At this point Mr Mskhiladze's legal representatives filed a petition to the RCC as this case demonstrated an important structural problem with the constitutional interpretation of the different elements of Russian law. First, there was the question of the length of $\mathrm{Mr}$ Mskhiladze's detention pending administrative removal (Article 31.9 CAO). The law did not 
require the trial judge to set any time limit when ordering detention of foreigners; as a result, and according to customary judicial practice, the time spent in detention became equal to the expiry of the statute of limitation for a particular immigration offence. That translated to $\mathrm{Mr}$ Mskhiladze - or any other foreign national, asylum seeker or a stateless person - being kept in detention for a minimum of two years or potentially indefinitely. The second structural problem was revealed by the unsuccessful petition of the Federal Bailiffs Service to terminate the enforcement proceedings against Mr Mskhiladze (Article 31.7 CAO). As a result, $\mathrm{Mr}$ Mskhiladze was kept in detention without the opportunity to have the length and legality of his detention judicially reviewed.

In its landmark Mskhiladze decision from May 2017, the RCC found the above elements of Russian law (Arts. 31.7 and 31.9 CAO) unconstitutional to the extent those:

did not allow to resolve in court the question of the lawfulness of continued detention of stateless persons sentenced to administrative removal and placed in detention centres, (...) in circumstances (...) where there was no actual possibility of enforcing the removal (Decision of RCC, 23 May 2017, No. 14-P, p. 26, my emphasis, thereafter 'RCC Decision').

The Constitutional Court defined the detention of stateless persons as deprivation of liberty not only with regard to Article 22 of the Russian Constitution, but also Article 5 ECHR, and the ECtHR jurisprudence. The RCC judges noted that deprivation of liberty 'can acquire a variety of forms that are not always identical to imprisonment in its classical sense' (RCC Decision, p. 12). The RCC further affirmed that:

any deprivation of liberty must meet the [European] Convention's criteria for protecting the individual from arbitrariness of the authorities, and the base of its 
legality cannot be interpreted broadly, since [any deprivation of liberty constitutes an] exception to the fundamental guarantees of personal freedom (RCC Decision, p. 12).

The lack of clarity of the immigration law concerning the detention of foreign nationals whom it was impossible to remove from Russia meant that the domestic legislation did not meet the criteria set by the Convention. In this context, the RCC also made explicit references to the ECtHR jurisprudence against Russia, and the general measures specified in another case of a stateless person sentenced to administrative removal - Mr Roman Anatolyevich Kim, a former USSR citizen born in Uzbekistan. In Kim v Russia, (application no. 44260/13, judgment 17 July 2014) the Strasbourg Court obliged the Russian Federation to 'secure in its domestic legal order, a mechanism which allows individuals to initiate proceedings for the examination of the lawfulness of the detention pending removal' (para 71, Kim v Russia). Given the two-year length of the detention, deemed by ECtHR as unreasonable, the Kim v Russia judgment also obliged Russia take 'the necessary general measures to limit detention periods so that they remain connected to the ground of detention applicable in an immigration context' (para 72, Kim v Russia). The RCC, by referring to this judgment, affirmed the necessity of these general measures in the domestic context and provided an additional important stimulus from within the domestic legal system for the Russian Duma to introduce specific legislation.

Until this new law is in place, the RCC put forward an interim measure, whereby stateless persons placed in detention pending administrative removal should be granted the right to appeal to court to review the legality of their further detention 'either where there is no evidence of actual possibility of their deportation, or after three months from the date of the imposition of administrative penalty' (RCC Decision p. 27). The RCC went even further and suggested that the legislator creates 'a special migratory status for stateless persons in 
respect of whom the administrative removal from the Russian Federation cannot be executed due to (...) the absence of a state willing to accept such a person' (RCC Decision p. 27).

This position of the Russian Constitutional Court was further strengthened by the decision of the European Court of Human Rights in the case Mskhiladze v Russia delivered six months later (application no. 47741/16, judgment of 13 February 2018). ${ }^{8}$ The ECtHR ruled that the prolonged detention of Mr Mskhiladze, especially in the context of his statelessness amounted to the violation of Articles 5(1) and 5(4) ECHR - right to liberty and security. The Strasbourg Court awarded Mr Mskhiladze 7,500 EUR of compensation.

\section{Legal productivity of statelessness}

In the immediate aftermath of the RCC ruling, Mr Mskhiladze was released from detention and his case put for fresh consideration before the domestic courts. However, as I argue in this paper, the consequences of the Constitutional and Strasbourg court rulings go well beyond this individual case. This RCC decision effectively stipulated that, if deportation or administrative removal is not effected within three months, then the point of future detention is questionable also from a human rights perspective, and should therefore be reviewed before domestic courts. The subsequent developments reveal how the protections affirmed explicitly with regard to de jure stateless persons can extend to de facto stateless, who may be nationals of a particular country but whose nationality is ultimately ineffective.

Why was the case of de jure stateless Mr Mskhiladze a good test case to fight? The Russian justice system generally does not inspire much confidence. There are many scholarly

\footnotetext{
${ }^{8}$ The legal representatives of Mr Mskhiladze applied to ECtHR in parallel to launching a case with the RCC. Filing an application to Strasburg upon the exhaustion of domestic remedies is the final resort in many immigration and refugee law cases in Russia (Kubal 2019).
} 
works that point to its many and various ills - lack of judicial independence, influence of politics (Ledeneva, 2013; Sakwa, 2010), and the persistence of the telephone law (Ledeneva, 2008). A number of high-profile cases - for example the Pussy Riot or of the chair of Yukos, Mr Mikhail Khodorkovsky - show in abundance how the legal system can be diverted by big politics. However empirical researchers of the Russian legal system will argue that while the judgments in the high-profile cases might be prepared outside of the courtroom, many mundane and everyday cases are adjudicated in accordance with the law (Hendley, 2007, 2009, 2012, 2017; Kubal, 2018; Kurchiyan \& Kubal, 2018a, 2018b). As Kathryn Hendley observed, 'the noise produced by these high-profile cases can mask a reality in which the vast majority of cases being brought to the courts are being processed [...] without any outside interference' ( 2015: 532). These ordinary cases are decided, however, in accordance to specific dynamics (Kahn, 2010; Kubal, 2018) and the broader legal culture (Kurkchiyan, 2009). The discussion of these dynamics sheds more light on why Mskhiladze became such a successful 'test' case to argue for the rights of other de facto stateless noncitizens in Russia.

Russian judges are not activist judges; they are rather conservative and attached to the literal interpretation of the law (Hendley 2012). Their judgments could be characterised by legal formalism that has moved to the extreme and became a way of thinking - draining the law of its content and spirit, so it remains only as a form (Kurkchiyan 2009). Any attempt by the Russian judges to exercise discretion so as to match the content of the law to a particular situation that arises in practice can therefore be easily regarded as a manipulation or outright violation of the law (Kurkchiyan 2009: 355). Therefore the judges, in their everyday rulings, prefer to stick to the written text of the law and its literal interpretation (Kubal 2019). In addition, Russian judges drown in paper - favouring written evidence contained in the case file over the power of adversarial arguments. 'Quod non est in actis, non est in mundo' What is not kept in the case file, does not exist (Kahn 2010: 107) - this old Latin saying 
summarizes the culture of materiality that characterises much of the legal process. In other words, any arguments or petitions by each side to the legal proceedings have to be supported by written documents contained in the case file in order to have a chance to succeed. Finally, and in comparison to many European civil judges, Russian judges are quite overworked (Hendley, 2012: 344). Some low-level judges, who also handle immigration cases, decide on average 200 cases per month, 'a pace that seems incredible' (Hendley 2013: 808). All these factors point to the conclusion that a legal argument that can warrant their attention has to be unambiguous, clear-cut, and supported by obligatory written evidence - official letters, documents, correspondence, multiple spravkas [references] and reports. The case of $\mathrm{Mr}$ Mskhiladze fit these criteria perfectly: he was a stateless USSR national and Georgia had confirmed in writing and on multiple occasions, that Mr Noe Mskhiladze had never been a Georgian national. A critical mass of documentary evidence was deposited in the case file to give credibility to the lawyer's argument that Mr Mskhiladze was de jure stateless. His deportation was impossible to enforce, as Mr Mskhiladze had no country willing to admit him, which put into question the lawfulness of his prolonged detention. The Constitutional Court saw this argument very clearly. Mskhiladze was a strong case because it was so manifestly blatant. Furthermore, Mr Mskhiladze, although now stateless, was a former USSR national. His detention was symptomatic of a broader issue - an existence of a substantial group of former USSR citizens who, in the thirty years since the collapse of the Soviet Union, had never acquired any other citizenship. This needed to be addressed as matter of historical and social justice. The RCC recognized this by setting a clear three-month limit on detention warranting a judicial review (oversight).

Once the decision of the Constitutional Court was announced in Mr Mskhiladze case, this judgment became a legal tool in the hands of pro-bono immigration and refugee lawyers from the 'Migration and Law' network (Kubal 2019). These cause lawyers literally stopped at 
nothing to push the boundaries of its interpretation. They extended the Mskhiladze judgment to pursue broader projects of securing human rights to liberty and freedom from detention for all noncitizens and de facto stateless persons in precarious legal situations in Russia. One lawyer argued passionately:

Should Mskhiladze be applied only to stateless persons or can it be extended to all detainees whom it is impossible to deport? I say it extends to all! My practice showed this time and time again, Mskhiladze works not only for stateless persons but also Ukrainian citizens whom it is impossible to deport, and other foreign citizens.

Another noted:

It boils down to what a detention centre should be... In my opinion, it should be a place where people stay days, not months and years. With stateless persons, or when the receiving country does not take jurisdictional responsibility - what is the point of keeping a person like in prison $[v$ nevole $]$ ?

The case of Mr Mskhiladze has effectively become a catalyst, a critical juncture that exposed the limits of Russian immigration law but also challenged those limits with wide ranging repercussions for other not necessarily stateless noncitizens. This ruling therefore 'opened the door for release from detention of not only stateless persons, but all migrants who spend more than three months in detention centres and de facto can be considered stateless persons' (Tseytlina, 2018: 37).

According to the statistics of the 'Migration and Law' network, between 2017-2018, over 100 cases were filed with courts all over Russia to have these noncitizens, de facto stateless persons, released from detention due to the impossibility of deporting them (Burtina, 2018b). The lawyers were successful in over 60 per cent of these cases - the appeals courts overturned the earlier decisions by excluding the deportation and ordering the defendants to be released from detention (Burtina, 2018b). 
The largest group and the one that particularly benefited from the Mskhiladze judgment were people in precarious legal situations who arrived in Russia due to the recent conflict in Eastern Ukraine (Kuznetsova, 2017). They formed a new de facto stateless group within the post-Soviet space that testified to the legal productivity of the Mskhiladze judgement. Given the deeply rooted conservatism of the Russian judges (Hendley, 2007, 2012), and legal formalism in interpreting the law (Kurkchiyan, 2009), these cases really pushed the conformist Russian judges to the frontiers of their creativity.

A word of context is required. Many civilians fled Donetsk and Luhansk areas toward the Central and Western Ukraine when the military conflict in Eastern Ukraine started. The UNHCR estimates that, as of 2019, the protracted conflict produced around $1.5 \mathrm{~m}$ internally displaced persons in Ukraine (UNHCR, n.d.). Around 1m Ukrainian citizens from the conflict affected areas decided, however, to flee to Russia (Mukomel, 2017: 10). Russian authorities adopted legislation significantly simplifying the rules for granting temporary asylum for Ukrainian citizens (Roudik \& Yatsunska, 2016); more than 300,000 Ukrainians received temporary asylum in Russia, and later citizenship (Polovinko, 2019). Others regularised their situation via the migrant worker route by securing a work licence or a work permit. However those who did not manage - due to a variety of reasons, including bureaucratic problems with the implementation of the law 'on the ground' - to regularise their status in Russia were treated by the immigration authorities as 'ordinary immigration offenders' (Kubal, 2016). The FMS, and its successor, GUVM MVD, prioritised their removal over recognizing their claims to international humanitarian protection. These Ukrainian citizens were placed in detention centres and awaited deportation that turned out, however, impossible to enforce due to the conflict in Eastern Ukraine. Furthermore, when the passports of many of the detainees expired, the central Ukrainian authorities refused to issue them certificates of citizenship given the 'impossibility to confirm this fact with the local authorities in Luhansk and Donetsk 
oblasts' (Burtina, 2018a: 14). The refusal of the Ukrainian government to admit its own citizens could be interpreted as a politically motivated decision - these men and women chose to flee the conflict toward Russia, viewed as an aggressor and a party to the conflict (Rettman, 2019). This led to the creation of a new group of de facto stateless people in the post-Soviet space, who, alongside refugees and internally displaced persons in Ukraine, became yet another human consequence of the military conflict in Eastern Ukraine (Pikulicka-Wilczewska \& Uehling, 2017). They were placed in Russian detention centres potentially indefinitely, not necessarily because there was no country willing to take them back, but because of the refusal of their own country to readmit them.

Russian immigration lawyers relying on the provision in the Mskhiladze judgment started pursuing the cases of these de facto stateless Ukrainians before the domestic courts. They secured a number of reversals (Burtina, 2018a, 2018b) - particularly in St Petersburg, Ekaterinburg, Moscow and Rostov-on-Don. Below I discuss one such case of a Ukrainian national, 'Mr Yakubov'. 'Mr Yakubov' is a composite character; I use this form to preserve the anonymity of the different individuals who benefited from the Mskhiladze judgment, but also to help the reader understand the overall conditions accompanying the emergence of this new group of de facto stateless Ukrainians in Russia.

'Mr Roman Yakubov' arrived in Russia from the Luhansk oblast in Eastern Ukraine in spring 2014. Throughout his stay in Russia, he had a number of different legal statuses, but he did not manage to secure any of them for longer than a year. Initially he applied for a work licence, but given that his employment was not stable, he could not gather enough money to pay the fee to renew it. He then tried to apply for a temporary asylum, but the authorities questioned his application given that he previously had a work licence in Russia. In the meantime, his passport has expired; he feared returning to Luhansk and given that his house 
was partially bombed in the heavy military operations in the area, he really had nowhere and nothing to go back to. He stayed in Russia, working ad-hoc on different construction projects and getting paid cash-in-hand.

In September 2018, the immigration authorities raided a building site on which $\mathrm{Mr}$ Yakubov was working. He was, together with other migrant workers apprehended on the site, taken to the local district court, where he was sentenced to a fine and deportation - the minimum penalty for undocumented work in certain regions of Russia (Kubal, 2016). Given that he had no valid document for return, Mr Yakubov was placed in a detention centre. The Federal Bailiffs Service petitioned the Ukrainian embassy in Russia asking to confirm whether Mr Yakubov was indeed a Ukrainian citizen. The response received stated, however, that 'at present moment it is impossible to corroborate whether Mr Yakubov is indeed a Ukrainian citizen as access to the relevant documents is impeded by the military conflict in Eastern Ukraine'. Given the dispute over Mr Yakubov's citizenship, and the fact that he was not in possession of any identity documents that would enable him to cross the international border with Ukraine, the Court of Appeal ordered the termination of the legal proceedings against Mr Yakubov and released him from the detention centre. Mr Yakubov is now in the process of identity verification, upon completion of which, the Russian authorities - as obliged by the RCC ruling in Mskhiladze - will issue him with identity and residence documents. The new planned law 'On Stateless Persons' stipulates that these documents will be issued to all stateless persons in Russia regardless of when and where they came from, regardless of their past criminal record and/or entry restrictions related to decisions about deportation, expulsion and removal. ${ }^{9}$ Mr Yakubov's life - and the lives of other Eastern

\footnotetext{
${ }^{9}$ The bill prepared by the Ministry of Interior is in the final consultation stage and is to be debated in Russian Duma by the end of 2019 .
} 
Ukrainians released from detention - is less on the margins than before. Yet it took a case before the Russian Constitutional Court and the ECtHR to help reach this outcome and secure the rights of many de facto stateless former USSR citizens in Russia.

\section{Conclusion}

This paper demonstrated how statelessness, if strategically challenged, may become a catalyst leading to legally productive changes for other noncitizens - or de facto stateless persons - in precarious legal situations. This discussion was contextualised to the specific conditions of post-Soviet Russia, where, thirty years since the dissolution of the Soviet bloc, there are still people whose inclusion, dignity and recognition of full personhood are inhibited by the lack of any other citizenship than that of the (non-existent) Soviet Union. The decision of the Russian Constitutional Court in Mskhiladze had real-life repercussions for securing a number of releases from detention of many former USSR citizens, but also other undocumented migrants who had no country willing to 'take them back'. The greatest impact of the Mskhiladze ruling could be observed among a relatively new group of de facto stateless persons in the post-Soviet space: Eastern Ukrainians from the Luhansk and Donetsk oblasts, who left their homes due to the military conflict. Although many of them were given temporary asylum and ultimately citizenship in Russia, some did not manage to secure a legal status. Their detention soon proved indefinite, as Ukrainian authorities were unable to corroborate the fact of their citizenship. The immigration lawyers of the 'Migration and Law' network activated the Mskhiladze judgment to obtain their release from detention, attesting to the legal productivity of statelessness. Following the case of Mr Mskhiladze and its wider consequences among undocumented Ukrainians in Russia, revealed an intricate relationship between de jure and de facto statelessness. De jure statelessness, if strategically challenged, can be useful for effectuating rights and can pave the way towards achieving better legal 
protection for other vulnerable migrants and de facto stateless persons. This discussion has conceptual repercussions for the broader statelessness debate. Should statelessness be eradicated at all cost? This paper demonstrated how in an absence of a viable path to an effective citizenship, human rights legal framework around de jure statelessness can be mobilised to spearhead the protection of the rights of other noncitizens in the post-Soviet space.

This does not mean, however, that the situation of stateless persons in Russia paints now overall a rosy picture. Quite the contrary, the human rights lawyers continue to warn that 'thousands and thousands of stateless people living in the Russian Federation are either being held in detention centres or are living under the constant threat of detention' (Abramenko, 2019). Even though the Mskhiladze judgment yielded successful results in many cases launched on behalf of the stateless and de facto stateless persons in detention in Russia, there were also cases where the domestic judges continued bureaucratic foot-dragging with regard to the guidelines of the Constitutional Court (Burtina 2018b). These people are likely to face continued detention at least until the formal legalization procedures are determined at the legislative level and the new law 'On Stateless Persons' (Burtina 2018b) is passed and implemented. Nevertheless, the Mskhiladze case attests to the legal productivity of statelessness, demonstrating how the relationship between de jure and de facto statelessness in post-Soviet space can be mobilised to secure human rights for those whose citizenship protections are ultimately ineffective. 
Table 1. De facto stateless persons in long-term detention in Russia

\begin{tabular}{|l|l|}
\hline \multicolumn{1}{|c|}{ Country of origin } & Number of persons \\
\hline Ukraine & 66 \\
\hline Kazakhstan & 64 \\
\hline Uzbekistan & 53 \\
\hline Georgia & 52 \\
\hline Azerbaijan & 36 \\
\hline Tajikistan & 32 \\
\hline Kyrgyzstan & 15 \\
\hline Armenia & 12 \\
\hline Turkmenistan & 6 \\
\hline Belarus & 5 \\
\hline Lithuania & 2 \\
\hline Estonia & 351 \\
\hline Moldova & 2 \\
\hline Others (United States, Vietnam) & \\
\hline Total & \\
\hline
\end{tabular}

Source: Burtina \& Tseytlina, 2018. 
Bibliography

\section{Primary Sources:}

Decision of the Russian Constitutional Court in the case concerning the constitutionality of the Articles 31.7 and 31.9 of the Code of Administrative Offences in connection with a complaint of a stateless person, N.G. Mskhiladze from 23 May 2017, accessed from http://doc.ksrf.ru/decision/KSRFDecision272574.pdf on 28 September 2019.

Decision of the European Court of Human Rights, case of Mskhiladze v Russia, (Application no. 47741/16) from 13 February 2018, accessed from:

http://hudoc.echr.coe.int/eng?i=001-180846 on 21 September 2019.

\section{References:}

Bl, O. (2019). European Court of Human Rights again finds extended detention of stateless individuals illegal: two successful cases by ADC Memorial. Brussels. European Network on Statelessness. Accessed from:

https://www.statelessness.eu/blog/european-court-human-rights-again-finds-extendeddetention-stateless-individuals-illegaltwo?mc_cid=07b88fe3c8\&mc_eid=339b3e75ac on 10 April 2019.

Blitz, B. K., \& Otero-Iglesias, M. (2011). Stateless by any other name: refused asylumseekers in the United Kingdom. Journal of Ethnic and Migration Studies, 37(4), 657573.

Bloom, T., Tonkiss, K., \& Cole, P. (2017). Introduction. Providing a framework for understanding statelessness. In T. Bloom, K. Tonkiss, \& P. Cole (Eds.), Understanding Statelessness (pp. 1-14). London and New York: Routledge.

Brubaker, W. R. (1992). Citizenship struggles in Soviet successor states. International Migration Review, 26(2), 269-291. 
Buckley, C. J., Blair A. Ruble, \& Hofmann, E. T. (2008). Migration, Homeland and Belonging in Eurasia. Washington DC,: Woodrow Wilson Center Press.

Burtina, E. (2018a). Court practice regarding the release of Stateless Persons from detention following the decision of the Russian Constitutional Court from 23 May 2017 in Mskhiladze case. In E. Burtina \& O. Tseytlina (Eds.), Stateless persons in the temporary detention centers for foreign nationals of the Ministry of the Interior: statistics, legislation, law enforcement (pp. 43- 56). Moscow: Human Rights Centre Memorial.

Burtina, E. (2018b). New trends in protecting the rights of stateless persons in Russia. Moscow: Human Rights Centre Memorial

Burtina, E., \& Tseytlina, O. (2018). Stateless persons in the temporary detention centers for foreign nationals of the Ministry of the Interior: statistics, legislation, law enforcement. Moscow: Human Rights Centre Memorial.

Chinn, J., \& Truex, L. A. (1996). The question of citizenship in the Baltics. Journal of Democracy, 7(1), 133-147.

Cole, P. (2017). Insider theory and the construction of statelessness. In T. Bloom, K. Tonkiss, \& P. Cole (Eds.), Understanding Statelessness (pp. 255-267). London and New York: Routledge.

Fein, L. C., \& Straughn, J. B. (2014). How citizenship matters: narratives of stateless and citizenship choice in Estonia. Citizenship Studies, 18(6-7), 690-706.

Geertz, C. (2008). 'Thick description: Toward an interpretive theory of culture' in T. Oakes and P. L. Price (eds) The cultural geography reader, London: Routledge: 41-51.

Gruberg, S. (2011) "De Facto Statelessness among Undocumented Migrants in Greece." Georgetown Journal on Poverty Law and Policy 18(3), 533-550.

Hendley, K. (2007). Are Russian Judges Still Soviet? Post-Soviet Affairs, 23(3), 240-274. 
Hendley, K. (2009). 'Telephone Law' and the 'Rule of Law:' The Russian Case. Hague Journal on the Rule of Law, 1(2), 164-241.

Hendley, K. (2012). The Unsung Heros of the Russian Judicial System: The Justice-of-thePeace Courts. Journal of Eurasian Law, 5(337).

Hendley, K. (2013). "Too much of a good thing? Assessing access to civil justice in Russia." Slavic Review 72(4): 802-827.

Hendley, K. (2015). Resisting Multiple Narratives of Law in Transition Countries: Russia and Beyond. Law \& Social Inquiry, 40(2), 531-552.

Hendley, K. (2017). Everyday Law in Russia. Ithaka and London: Cornell University Press.

Hirschman, A. O. (1970). Exit, voice, and loyalty: Responses to decline in firms, organizations, and states. Cambridge, MA: Harvard University Press.

Humphrey, C. (2002). The unmaking of Soviet life: everyday economies after socialism: Cornell University Press.

Kahn, J. (2010). Adversarial Principles and the Case File in Russian Criminal Procedure. In K. Malfliet \& S. Parmentier (Eds.), Russia and the Council of Europe: Ten Years After (pp. 107-133 ). Basingstoke: Palgrave Macmillan.

Kingston, L. N. (2014). Statelessness as a lack of functioning citizenship. Tilburg Law Review, 19(1-2), 127-135.

Kubal, A. (2019). Immigration and Refugee Law in Russia. Socio-Legal Perspectives. Cambridge, Cambridge University Press.

Kubal, A. (2017). "Entry Bar as Surreptitious Deportation? Zapret na v'ezd in Russian Immigration Law and Practice: A Comparative Perspective." Law \& Social Inquiry 42(3): 744-768. 
Kubal, A. (2018). In Search of Justice: Migrants' Experiences of Appeal in Moscow City Court. Sociology of Justice in Russia. M. Kurkchiyan and A. Kubal. Cambridge, Cambridge University Press: 92-117.

Kubal, A. (2016). "Spiral effect of the law: migrants' experiences of the state law in Russia a comparative perspective." International Journal of Law in Context 12(4): 453-468.

Kurkchiyan, M. (2003). The Illegitimacy of Law in Post-Soviet Societies. In D. J. Galligan \& M. Kurkchiyan (Eds.), Law and Informal Practices: The Post-Communist Experience (pp. 25-47). Oxford: Oxford University Press.

Kurkchiyan, M. (2009). Russian Legal Culture: An Analysis of Adaptive Response to an Institutional Transplant. Law \& Social Inquiry, 34(2), 337-364. doi:10.1111/j.17474469.2009.01149.x

Kurkchiyan, M. and A. Kubal, Eds. (2018). A Sociology of Justice in Russia. Cambridge Studies in Law and Society. Cambridge, Cambridge University Press.

Kuznetsova, I. (2017). Dangerous and Unwanted: Policy and Everyday Discourses of Migrants in Russia. In A. Pikulicka-Wilczewska \& G. Uehling (Eds.), Migration and the Ukraine Crisis: A Two-Country Perspective (pp. 149-163). Bristol: EInternational Relations Publishing.

Lambert, H. (2018) 'Nationality and Statelessness Before the European Court of Human Rights: A landmark judgment but what about Article 3 ECHR?' Strasbourg Observers Blog, 16 May 2018, accessed from https://strasbourgobservers.com/2018/05/16/nationality-and-statelessness-before-theeuropean-court-of-human-rights-a-landmark-judgment-but-what-about-article-3-echr/ on 8 January 2020.

Landolt, P., \& Goldring, L. (2015). Assembling noncitizenship through the work of conditionality. Citizenship Studies, 19(8), 853-869. 
Ledeneva, A. (2008). Telephone Justice in Russia. Post-Soviet Affairs, 24(4), 324-350. doi:10.2747/1060-586X.24.4.324

Ledeneva, A. (2013). Can Russia Modernize? Sistema, Power Networks adn Informal Governance. Cambridge: Cambridge University Press.

Levin, I. (2018). Caught in a bad romance: displaced people and the Georgian state. Citizenship Studies, 22(1), 19-36.

Massey, H. (2010). "UNHCR and de facto statelessness." Legal Protection and Policy Research Series Accessed from: https://www.refworld.org/docid/4bbf387d2.html on 2 July 2019.

McCarthy, L. (2018). Decision-Making in the Russian Criminal Justice System: Investigators, Procurators, Judges and Human Trafficking Cases. In M. Kurkchiyan \& A. Kubal (Eds.), Sociology of Justice in Russia (pp. 205-230). Cambridge: Cambridge University Press.

Mukomel, V. (2017). Migration of Ukrainians to Russia in 2014-2015. Discourses and Perceptions of the Local Population. In A. Pikulicka-Wilczewska \& G. Uehling (Eds.), Migration and the Ukraine Crisis: A Two-Country Perspective (pp. 105-116). Bristol: E-International Relations Publishing.

Parsons, L., \& Lawreniuk, S. (2018). Seeing like the stateless: Documentation and the mobilities of liminal citizenship in Cambodia. Political Geography, 62, pp. 1-11.

Pikulicka-Wilczewska, A., \& Uehling, G. (2017). Migration and the Ukraine Crisis: A TwoCountry Perspective Bristol: E-International Relations Publishing.

Pilkington, H. (1998). Migration, displacement, and identity in post-Soviet Russia. London, New York: Routledge.

Polovinko, V. (2019). Rejection of people based on ethnicity - interview with Svetlana Gannushkina. Novaya Gazeta, 11 March 2019, 
Redclift, V. (2013a). Statelessness and Citizenship: Camps and the Creation of Political Space. London: Routledge.

Redclift, V. (2013b) “Abjects or Agents? Camps, Contests and the Creation of 'Political Space'.” Citizenship Studies 17 (3-4): 308-321.

Rettman, A. (2019). Russia's grey war in Ukraine prompts fatigue. EUObserver. Retrieved from https://euobserver.com/foreign/144084 on 12 September 2019.

Roudik, P., \& Yatsunska, O. (2016). Refugee Law and Policy: Russian Federation. Washington: Library of Congress, Retrieved from https://www.loc.gov/law/help/refugee-law/russianfederation.php on 3 October 2019.

Sakwa, R. (2010). The Dual State in Russia. Post-Soviet Affairs, 26(3), 185-206. doi:10.2747/1060-586X.26.3.185

Shevel, O. (2009). The politics of citizenship policy in new states. Comparative Politics, 41(3), 273-291.

Shevel, O. (2012). The Politics of Citizenship Policy in Post-Soviet Russia. Post-Soviet Affairs, 28(1), 111-147. doi:10.2747/1060-586x.28.1.111

Sigona, N. (2016). "Everyday statelessness in Italy: status, rights, and camps." Ethnic and Racial Studies 39(2): 263-279.

Swider, K. (2017). Why end Statelessness? In T. Bloom, K. Tonkiss, \& P. Cole (Eds.), Understanding Statelessness (pp. 191-209). London and New York: Routledge.

Tseytlina, O. (2018). The problem of restricting the freedom of foreign citizens and stateless persons in the light of the decisions of the European Court of Human Rights and the Constitutional Court of the Russian Federation. In E. Burtina \& O. Tseytlina (Eds.), Stateless persons in the temporary detention centers for foreign nationals of the Ministry of the Interior: statistics, legislation, law enforcement (pp. 23-43). Moscow: Human Rights Centre Memorial. 
UNHCR. (2014). Global Action Plan to End Statelessness. Accessed from https://www.unhcr.org/ibelong-campaign-to-end-statelessness.html on 1 March 2019 UNHCR. (n.d.). Internally Displaced Persons in Ukraine. Accessed from https://www.unhcr.org/ua/en/internally-displaced-persons on 20 March 2019 UNHCR (2018). Statistical Yearbook for 2016 - 16th Edition. Geneva, UNHCR. Accessed from https://www.unhcr.org/uk/statistical-yearbooks.html on 10 April 2019.

Vetik, R. (2011). The statelessness issue in Estonia. In C. Sawyer \& B. K. Blitz (Eds.), Statelessness in the European Union: Displaced, Undocumented, Unwanted (pp. 230 252). Cambridge: Cambridge University Press.

Vlieks, C. (2017). Contexts of statelessness. The concepts 'statelessness in situ' and 'statelessness in the migratory context'. In T. Bloom, K. Tonkiss, \& P. Cole (Eds.), Understanding Statelessness (pp. 35-52). London and New York: Routledge.

White, P. (2009) Reducing de facto statelessness in Nepal. Forced Migration Review 32(04), pp. 28-29. 